Ouachita Baptist University

Scholarly Commons@Ouachita

Articles

Faculty Publications

$12-2014$

\title{
South Africa's History of Struggle and Liberation
}

Myra Ann Houser

Ouachita Baptist University, houserm@obu.edu

Follow this and additional works at: https://scholarlycommons.obu.edu/articles

Part of the African History Commons, African Studies Commons, Inequality and Stratification

Commons, Other History Commons, $\underline{\text { Politics and Social Change Commons, and the Race and }}$

Ethnicity Commons

\section{Recommended Citation}

Houser, Myra Ann, "South Africa's History of Struggle and Liberation" (2014). Articles. 42.

https://scholarlycommons.obu.edu/articles/42

This Book Review is brought to you for free and open access by the Faculty Publications at Scholarly Commons @ Ouachita. It has been accepted for inclusion in Articles by an authorized administrator of Scholarly Commons @ Ouachita. For more information, please contact mortensona@obu.edu. 
Liberation Movements in Power: Party and State in Southern Africa. By ROGER SOUTHALL. Pietermaritzburg: University of Kwa-Zulu Natal Press, 2013. ix + 384 pp. ISBN:

9781869142483.

In the wake of Marikana, a former freedom struggle participant expressed that, for the first time following a tragic public event, she felt hopeless. "This was supposed to be our government. This wasn't supposed to happen." 1

The state of the state in post-liberation southern Africa, unsurprisingly, has garnered some head wringing, much conversation, and the spilling of just as much ink. As the emotional and idealistic have given way to oft-difficult realities, the ink continues to flow. Roger Southall's Liberation Movements in Power: Party and State in Southern Africa provides a welcome, rigorous analysis in this expanding field. The book focuses on the histories and contemporary standings of three national liberation movements-turned political parties: the African National Congress (ANC), South West African People's Organization (SWAPO), and Zimbabwe African National Union--Patriotic Front (ZANU-PF), asking why the chasm between expectation and reality in post-liberation society seems so wide. While Southall argues that national liberation movements (NLMs) remain bounded by their histories, he avoids presenting a narrative of inevitability. Liberation Movements in Power packs its information densely and should be widely read.

The author begins his study, naturally, by introducing readers to NLMs and explaining their centrality to the development of African nationalism and freedom struggles. He argues, and later demonstrates, that the struggles created an "exclusive nationalism (5)." In acknowledging that Africanists have largely moved past this exclusivist view, he argues that it continues to fit NLM behaviour and attitudes.

Southall's first chapter focuses on the region' s unique history. Following a discussion of colonialism generally, he notes that "the migration of whites from Europe to far-flung countries was one of the defining aspects of the historical expansion of Empire, its impact upon indigenous peoples brutal where not genocidal . . . conjunctures of history and economics were to see white settlement take pace in a handful of countries identified as both habitable and useful to the imperial enterprise. The resultant phenomenon of 'settler colonialism' was to have dynamics which distinguished it from other forms of colonialism found elsewhere in Africa - and to give rise to 'armed struggle.' Hence 'settler colonialism' constitutes the starting point for any historical understanding of the liberation movements today (17)." Southall moves (perhaps too?) quickly through constructions of race, capitalism and colonial economies, and the "political rigidity" that settler societies created (28). He then discusses the evolution of NLMs themselves, framing his study through the works of Andre Odendaal, Saul Dubow, Phil Bonner, Martin Meredith, Alex Callinicos, and Peter Katjiavivi, among others in a cannon that has grown considerably in the two years since Liberation Movements in Power's publication. ${ }^{2}$

\footnotetext{
1 "Service of Remembrance for the Events in Marikana on August 16, 2012" program. August $28,2012$. Metropolitan American Methodist Episcopal Church, Washington, DC.

${ }^{2}$ Andre Odendaal. Vukani Bantu!: The Beginnings of Black Protest Politics in South Africa to 1912 (Cape Town: David Phillips, 1984); Saul Dubow. The African National Congress (Johannesburg: Jonathan Ball, 2000); Phil Bonner. "Plenary Presentation to the Conference 'One Hundred Years of the ANC: Debating Liberation Histories
} 
Chapter three, 'The War for Southern Africa,' rounds out the historical contextualization with a discussion of the 1960s-1990s. Southall focuses on the role of exile in creating exclusive nationalism, competition among liberation movements, and the role of secrecy in keeping each afloat. The author also pays attention to the ad hoc nature of liberation campaigns, notably the 1970s South African student protests (54), arguing that NLMs often acted in reactionary ways, not the triumphant ones they have since projected. Finally, Southall contextualizes southern African freedom struggles in relation to Cold War powers.

Chapters four and five move through negotiations for national liberation, elections, and subsequent polling victories. The author begins by telling us that "settler populations lost political power in exchange for guarantees of rights of minorities and property; liberation movements were promised control of the state in exchange for an accommodation with domestic and international capital. However, there were fundamental contradictions at the heart of all of this (65)." The contradictions existed, he explains, not just within political settlements that privileged compromise but also, soon, within NLMs themselves. Here, he bookends with Zimbabwe' s Lancaster House accords and a brief introduction to economic policy. This paragraph contains one of the book's greatest strengths. Southall draws upon his previous comments about historical trajectories to ask what the movements represented not just for people pinning hopes upon freedom struggles, but also for those excluded or self-detached from liberation victories. Here, he begins with John Saul's assertion that NLMs simultaneously sought "liberation from gender, ethnic, and economic oppressions as well as from the racial oppression of the settler state (69)," then cites the idealism of Mandela, Hani, Tambo, et. al. as one iteration of this freedom that, he argues, often sought majority rule over democracy. In this context, he warns readers, "we need to question how deeply aspirations for an expansive liberation were shared, especially among overwhelmingly male leaderships subject to militarist influences (69)." While in Chapter four Southall notes the threats that negotiated constitutions posed to NLM hegemonies, much of Chapter five focuses on threats from opposition parties, many of which, of course, began as liberation movements themselves.

The next three sections detail NLMs' relationships with state, society, and economic transformation following the 'capturing' of the state. Here, Southall argues that, while the terms of settlements now seem distant, NLMs often feel no longer obligated nor willing to placate political opposition. In the seventh chapter, Southall widens his discussion on this competition to include not just other parties, but social groups such as trade unions, civic organizations, and churches. He discusses each group's relationship to NLMs and the impact that international trade and organizations, rural and urban divides, and the media have played in those. He ends by asking, provocatively, whether NLMs are "machines against society (210)," subverting society interests to exclusivist political ones. Chapter eight takes us through

and Democracy Today' (20-24 September, 2011); Martin Meredith. Robert Mugabe: Power, Plunder and Tyranny in Zimbabwe (Cape Town: Jonathan Ball, 2002); Luli Callinicos. Southern Africa After Zimbabwe (London: Pluto Press, 2001); Peter Katjavivi. A History of Resistance in Namibia (London: James Currey, 1988). 
Growth, Employment, and Redistribution (GEAR), Black Economic Empowerment (BEE), indigenization, land reform, and the continuing saga of multinational mineral extractors.

Chapters nine and ten deal with an emotional for many southern Africans and onlookers: the erosion of idealism. Southall discusses not just a lack of transformation, but a rise in "party predation (262)" based upon furthering the interests of elite and middle class southern Africans who participated (or not) in the struggle and pinned hopes for social mobility upon victory. Here, Southall demonstrates that (particularly external) financial support for NLMs largely declined after the heady days of liberation struggle, leading to the coopting of state resources for their maintenance. He dissects the transition from expensive liberation movements with a wide base of support to expensive political parties with "machine as monster? (291)."

This book' s final section engages a case study of the ANC under Thabo Mbeki and Jacob Zuma though, curiously, excludes similar discussions on Namibia and Zimbabwe. While Southall does pay attention here to 'Zuma Inc,' family and personal controversies, and GuptaGate, he focuses largely on the legacy of Polokwane and internal party struggles during the leaderships of Kgalema Mothlante, Mbeki, and Zuma. Eliding discussion only of the iconic Nelson Mandela and Government of National Unity (largely operated by Mbeki and Zuma at any rate), Southall argues for continuity between these diverse post-liberation administrations. He concludes with an extended discussion on legacies of Mangaung and the rise of Julius Malema's Economic Freedom Fighters. Liberation Movements in Power arrives at an appropriate time, yet just two years after its publication, this chapter seems nearly obsolete. Southall's work concluded too soon to address ANC responses to watershed moments such as Marikana (presumably), Nkandla and its media circus (though he does include a brief discussion of Zuma's security apparatchik), E-Tolls, Poo Protests, and a reawakening of student consciousness through campaigns such as \#RhodesMustFall and \#FeesMustFall. Indeed, finding current events to dissect in a continuously evolving political climate may be akin to catching the proverbial water in a sieve. Perhaps it is not too much to hope that Southall's future editions may more fully address this stunning, continuing turn from ANC as protest agitator to protest object.

In conclusion, Southall tells his readers that "we are reaching the end of an era in southern Africa" and asserts that this results from the "slow death of liberation movements (327)." Perhaps presciently, he issued this prognostication just months before the death of Mandela and, it could be argued, the symbolic death of the struggle itself. Despite its large claims, for the most part, Liberation Movements in Power grounds itself in deep statistical and historical analysis, successfully avoiding the idealism or cynicism (take your pick!) that often undergird such studies. That may not prove satisfying to those searching, like our friend in the beginning, for an "ideal government." But it does effectively answer (some of the) many whys and hows about contemporary governance and its myriad frustrations. In constructing a book that continues to move scholarly studies away from the (understandably) emotional and idealistic while also eschewing bitterness, Southall has helped set the stage for a new era not only in southern Africa' s history, but also in its historical and political analysis. 
Ouachita Baptist University 